Journal of Sustainable Development of Transport and Logistics

journal home page: https://jsdtl.sciview.net

Onwuegbuchunam, D. E., Okeke, K.O., Igboanusi, C., \& Ugboma, O. (2018). Structural changes in the global transport chain: Implications for ports. Journal of Sustainable Development of Transport and Logistics, 3(1), 22-28. doi:10.14254/jsdtl.2018.3-1.2.

\title{
Structural changes in the global transport chain: Implications for ports
}

\section{Donatus E. Onwuegbuchunam*®i, Kenneth 0. Okeke*, Chinemerem Igboanusi**, Ogochukwu Ugboma***}

\author{
* Federal University of Technology Owerri, \\ PMB 1526, Nigeria \\ Department of Maritime Management Technology \\ ** Federal University of Technology Owerri, \\ PMB 1526, Nigeria \\ Department of Transport Management Technology \\ *** Lagos State University, \\ Lagos - Badagry Express Way, PMB 0001 LASU Post Office, Nigeria \\ School of Transport
}

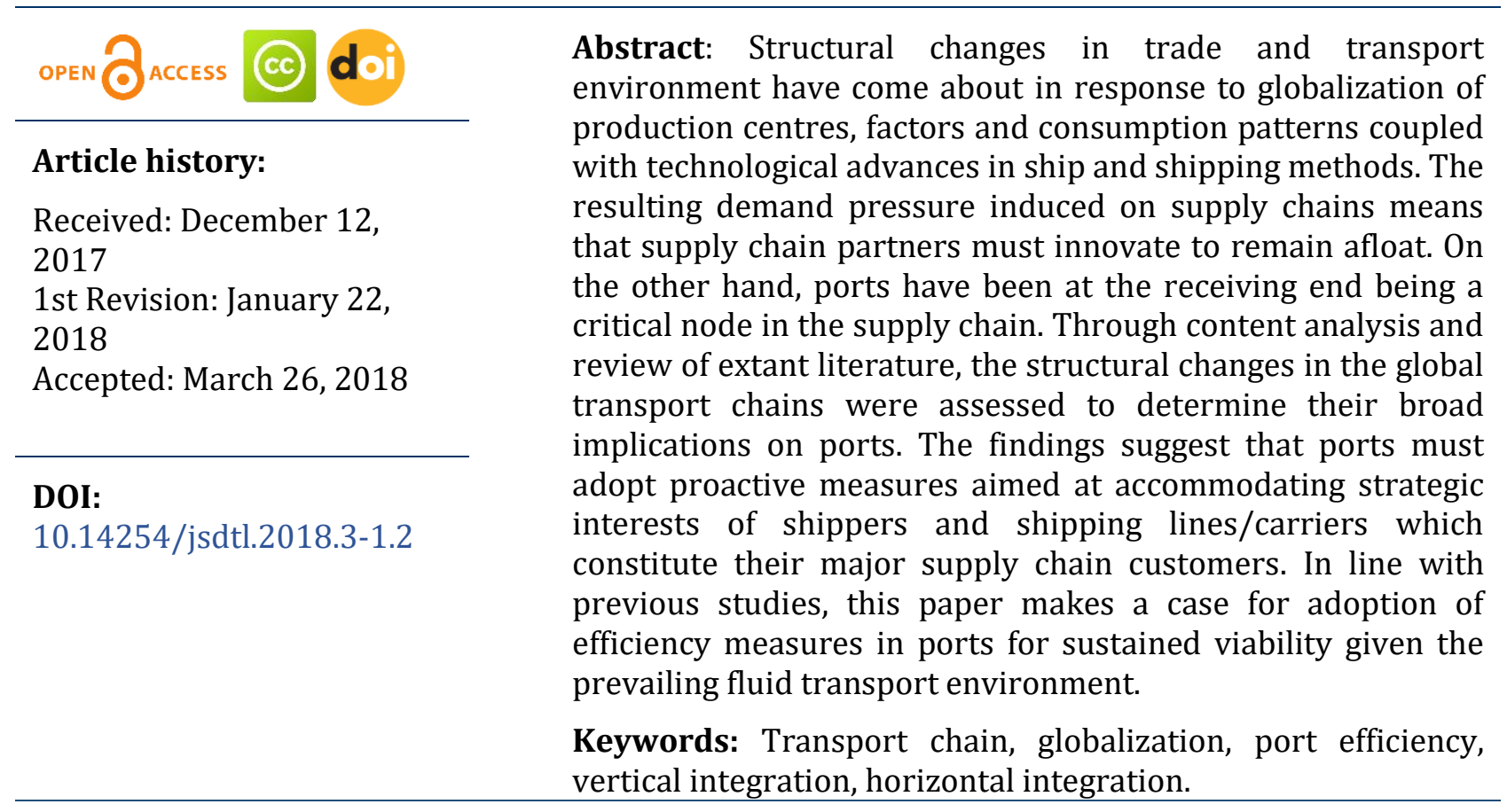

\section{Introduction}

Typically, transport of consignment between two trading countries will involve a combination of the following flows:

i. Movement of the consignment from warehouse factory of shipper to the port at origin country using inland mode or modes.

Corresponding author: Donatus E. Onwuegbuchunam

E-mail: donafutow@yahoo.com

This open access article is distributed under a Creative Commons Attribution (CC-BY) 4.0 license. 
ii. Seaward movement of consignment from origin country port to port of country of destination via the maritime mode(s)

iii. Movement from destination port to the buyer's or shipper's premises using inland mode(s).

The total combination of modes used and ports utilised to achieve the above flows could be regarded as transport chain. The choice to use a specific port by a carrier or shipper is an implied one, made in attempt to choose a network or transport chains that minimize generalized cost of transport. However, it seems reasonable to assume that the decision to choose a port and routing (transport chain) decisions are related (Onwuegbuchunam, 2013). Therefore a proper understanding of activities of transportation chain elements is relevant to the analysis of their impacts on ports. These could be examined by assessing changes in global liner shipping affecting shipping lines, shippers, logistic service providers etc. The changes have been brought about by: globalization of production and consumption patterns, emphasis on economies scale through employment of mega ships for shipping, formation of mergers and alliances (horizontal integration), acquisitions, intermodalism etc. and growing shift of emphasis from modal to logistics approach in transport operations (vertical integration).

Shipping lines for example, which have merged or are operating under alliance arrangements have become mega corporations (also known as global carriers). Such corporations have invested in logistics supply chain facilities and hence have the greatest influence in the details of inter-continental itineraries which seaports are part of. In addition, individual shippers are also many and have as much influence as the carriers in choosing port which minimize their cost in making shipments. For ports, just as no one shipper generates enough containerized cargoes to fill a mega ship, no one seaport has a captive hinterland large enough to ensure a permanent place in intermodal logistics chain. Thus, ports now have to compete based on efficiency of their services rather than on location. The forgoing is a synopsis of influences generated among the various elements in the transport chain which have great implication on port efficiency. Analysis of specific influence of these elements will provide a basic understanding of what underlies carriers and individual shippers transport choice and hence their port service demand behaviour.

\section{Conceptual Reviews: Structural developments in the global transport chain}

\subsection{Transport demand and use of megaships}

Since the advent of globalization, made possible by improved communication facilities and faster transport vehicles, geographical barriers among nations have literally been removed. Thus, industries now source abroad for production inputs as well as market their surplus abroad. The resulting efficiency achieved in production has generated intense demand for especially maritime transport notably among the world's most important industrial centres of North America, Northern Europe and Far East Asia. These major industrial centres are connected by Trans-Pacific, Trans-Atlantic and Far-East Asia Ocean corridors where the volume of container trade (main item of liner shipping) is highest. The volume of trade is the justification for the use of mega ships (to achieve economies of scale) along these routes. The use of mega ships by global carriers brought necessary network changes. Large container vessels have high daily operating costs and are routed to call at feeder ports to limit port calls and hence reduce operating costs. The high utilization of feeder services and transhipment ports by mega vessels have revived the trend toward load centres i.e. choosing ports on a voyage itinerary that not only have a strong traffic generating tributary hinterland but also are well located for transhipment purposes.

\subsection{Alliance formation}

The problem of overcapacity witnessed in International shipping brought intense pressure on freight rates and reduced profit margins. Carriers had to seek ways of maintaining adequate route coverage with minimum investment in ships. The most attractive strategy has been formation of alliance arrangement with other carriers. Alliances provide their members easy access to more loops or services with relatively low cost implications and allow them to share terminals, and to co-operate in many areas at sea and ashore, thereby achieving cost savings in the end. The object is to meet increasing global needs of shippers for access to suppliers and markets while using reduced number of carriers. Most of 
the top twenty (20) carries are now involved in multi-trade strategic alliances, See table 1. Shipping alliances help in reducing costs and increasing geographic reach by sharing ships and port facilities (Wagner, 2015). Carriers are viewing market mass as one of the most effective weapons in coping with a trade environment that is characterized by intense pricing pressure (Notteboom \& Winkelmans, 2001b). According to Baird (2002), once an alliance has been formed, member lines then search for further economies of scale.

\subsection{Mergers and acquisitions}

This is another phenomenon that has dominated the contemporary transport scene. Examples of mergers and takeovers are Hapag-Lloyd and CSAV (2014), CSCL + COSCO (2016) and NOL by CMA CGM (2016) (Chee, 2016), etc. Apart from increasing geographical span of services offered to shippers, shipping carriers consider the need to make investment in order to improve the characteristics of shipping services offered; to improve information services and intermodal arrangements and to extend warehousing and full supply chain management services. In widening the extent and range of their services, carriers have considered the scale of operations involved and cost implications. To reduce costs, mergers and acquisitions have been attractive options to carriers. These models create potentials for better use of central services and increase traffic density on routes.

\begin{tabular}{clc} 
Table 1: Deep Sea Alliances/ Carriers Market Share & Market Share \% \\
\hline S/No & Operator & 14.7 \\
\hline 1 & APM-Maersk & 13.3 \\
2 & Mediterranean Shg Co & 11.5 \\
3 & CMA-CGM + APL & 7.6 \\
4 & COSCO + CSCL & 4.6 \\
5 & Hapag-Lloyd + CSAV & 4.6 \\
6 & Evergreen Line & 4.2 \\
7 & COSCO & 3.5 \\
8 & CSCL & 3.2 \\
9 & Hamburg Süd Group & 3.1 \\
10 & Hanjin Shipping & 2.7 \\
11 & MOL & 2.7 \\
12 & OOCL & 2.7 \\
13 & Yang Ming Marine Transport Corp. & 2.6 \\
14 & APL & $\mathbf{8 1 . 0}$ \\
& Sub-total & $\mathbf{1 9 . 0}$ \\
& Other Carriers & $\mathbf{1 0 0}$ \\
\hline
\end{tabular}

Source: Drewry Maritime Advisers, 2016

\subsection{Intermodal arrangements}

The main units of cargo carriage employed by global carriers involved in liner shipping are the containers. Intermodality or simply put, transport through more than one mode, allows the best use of a container. An efficient intermodality system ensures fluidity of container flow and their repositioning. The need for better intermodal services arises out of the following:

i. The desire for improved transport service quality as shippers have shifted to reduced inventories in more responsive supply chains.

ii. The qualities of high service frequency, reliability of delivery and of capacity available are expected of the transport system, not just the shipping service.

Traditionally, the business of shipping lines was the movement of cargo on a port-to-port basis. This may still be true of small lines competing on a low cost strategy. It is also necessary for most or all liners in regions in which intermodal movements are impractical e.g. in West and Central African regions. But in Europe, North America and increasingly in Asia, all of the major shipping lines now offer door-to-door service. The percentage of intermodal arrangements made by the shipping lines is highest in North America where intermodal train service is well developed. In African still, shippers or 
forwarders play a great role in making the inland arrangement. The integration of sea shipping with inland services has been largely achieved through shipping lines managing as well inland transport systems. It has been done through a combination of long-term and short-term purchase. For instance, shipping lines have been leaders in the development of rail-dominated intermodal services in North America, Europe and China. These services have enabled the achievement of better through transport quality offered to shippers. The implication for such intermodal arrangements made by shipping lines (vertical integration) is that where physically practicable, the lines offer door-to-door service to shippers. Shipping has extended beyond the oceans to a door-to-door business. This notwithstanding, shippers have remained free to make their inland arrangements.

\subsection{Logistics outsourcing services}

Another development in the global transport chain is the outsourcing of logistics and associated function to service providers such as non-vessel operating common carriers (NVOCCS), third or fourthparty logistics (3PLs or 4PLs) providers and financial institutions. This is especially true of large shippers in Europe and America. Often times the objectives of multinational corporations (who are large shippers) cannot be realized due to limited capability of their resources. Outsourcing of logistic services has been an important strategic option to them. It has a way of making fixed costs variable and thus releasing internal resources for investment in core areas. In this era, three basic forms of outsourcing can be distinguished with regard to supply chain management (Notteboom \& Winkelmans, 2001) viz:

i. The outsourcing of production of components in which large production units are replaced by a network of suppliers organized on a global or local scale.

ii. Value-added logistics (VAL). Here some value creating activities like secondary manufacturing of productions are transferred to logistics service providers.

iii. The outsourcing of transportation, warehousing and distribution.

The implication of these developments is that shippers have transferred enormous transport responsibilities to carriers. They are no longer looking for straight shipping but want global logistic packages in which shipping and logistic services are integrated.

Third party logistics providers (3PLs) are the traditional intermediaries of the transportation industry and range from large multinational corporations covering a wide array of logistics services to small intermediaries that specialize in particular logistics function (Karimi et al., 2002). As shipment consolidators, 3PLs accumulate enough shipments from numerous small shippers to fill a container, which they then tender to a carrier. These small shipments, called less-than-container loads (LCLs), are charged on a volume basis, while full-container-loads (FCLs) are charged based on the size (TEU) of the container. Thus, outsourcing logistics functions has become common in the last two decades due to its numerous advantages. Shippers that do not have sufficient shipping volumes by themselves can obtain economies of scale by the consolidation offered by the 3 PLs /4PLs. Letting service providers manage logistics leads to efficient and effective warehousing operations and reduces logistics assets. The geographically distributed logistics network and transhipment offered by the providers may lead to shorter transportation times and lower costs. With well-developed IT infrastructure, IT solutions and track and trace capabilities many service providers can also increase real time visibility and control of materials during transport.

In summary, it can be seen from the foregoing that large shippers can contract out their logistics and distribution functions to shipping lines (carriers) or to other intermediaries like third party or fourth party logistic providers, who then transact directly with carriers. In both cases, transport responsibilities are borne by the business partners. This leads to cost reduction and efficiency. For carriers, transport responsibilities are enlarged. They can choose to operate straight shipping and sublet logistic (vertical integration) and inland distribution functions. For the small and medium sized shippers who cannot provide sufficient consignment to fill a container (LCL), advantage of economies of scale can be taken by making use of consolidation facilities provided by third party logistic service providers. The alternate strategies of lines involve organizational issues related to horizontal and vertical integration in liner shipping. Perhaps a little analysis of the economics behind such strategies will enhance understanding of issues motivating their decisions. 


\subsection{Economies of carrier strategies: Network size, economies of scale and scope}

Over the last 15 years, shipping has changed from an industry in which the worth of service to customers was largely dependent on its attributes on a trade route basis to an industry in which the extent of the network is as important to the value of services (Heaver, 2002). For large shippers high network coverage is very important. The addition of routes by a shipping line whether by alliance, merger or the extension of its own services is primarily a method of meeting customers' preferences for extended network size. The value placed by shippers on large route network has increased as their businesses have become more global (Heaver, 2002). For example, in 1995, when American President Line (APL) introduced its first service from Asia to Europe though a slot charter arrangement, it accounted for its move from a pacific only strategy as a response to the pressures from shippers for global coverage (Heaver, 2002). Further, the expansion of a service network in shipping can be costly, as in other network industries, if the density of services is reduced. The scope of service in the sense of the large geographical size of the network increases costs unless the enlarged network attracts sufficient traffic. This is why the entry of a line into a new service is often achieved through slot charters until there is sufficient traffic to justify provision of a full capacity (Heaver, 2002). The main economies of scale are economies of density achieved through the use of large sized vessels (mega ships) and through the use of large, efficient terminals and related systems (Heaver, 2002). Incidence of inefficient ports has forced shipping lines to have large terminals which they manage themselves not to service shippers but to better service their vessels on arrivals. The value placed by shippers on extent of network services and their interest in more sophisticated services consistent with the higher logistics performance required in modern supply chains have raised new roles for shipping companies (Heaver, 2002) - economies of scope.

\subsection{The economies of vertical control in shipping and logistics}

Vertical integration or control is exemplified in the involvement of shipping lines into inland and logistics functions as a result of the changing logistic needs of shippers. Advantages accruing to vertically integrated firm may be placed in three categories. First, there may be benefits in demand complementarity among business i.e. the customers of trucking service may carry through as customers of the shipping service (Heaver, 2002). Second, opportunities may exist for cost savings through the use of shared resources and expertise and through the avoidance or reduction of transaction costs among the businesses (Heaver, 2002). Third, benefits may arise from enhanced visibility (through common advertising) and market power and from diversifying the business base. Potential for benefit exists whether the integration is achieved through ownership, some form of alliance or through contracting (Heaver, 2002). The foregoing provides economic justification for the strategies of shipping lines discussed. However, there are criticisms. Demand complementarity is weakened by three conditions as put forward by Heaver (2002). First, traditional horizontal agreements among lines in shipping conferences and similar agreements inhibit sophisticated negotiations between individual lines and shippers (Heaver, 2002). Second, shipping and especially logistics services are provided in highly competitive markets. When the choices of services are numerous and the substitutability among services is high, the chance of demand complementarity is low (Heaver, 2002). Third, purchasers of logistics and transportation services are sophisticated buyers. They will be reluctant to use a logistic service if they feel it is designed to serve as a 'feed' to another business (Heaver, 2002). The balance between advantages and disadvantages of vertical integration varies among regions and industries and with the condition and characteristics of particular firms. Large shippers with global service requirements appear more interested in entering into integrated supply chain service arrangement than other shippers. Thus varied interests among shippers have resulted in varied levels and forms of integration existing among lines.

In summary, the following strategies highlight the business strategies of shipping lines: Restructuring: this entails concentration and rationalization via mergers and acquisitions and strategic alliances. Differentiation: entails offering differential services via door-to-door transportation solutions as part of total logistics services and seeking greater operational coverage and scale economies by deploying bigger vessels and transhipment strategies. These strategies have had great implications on ports. 


\section{Addressing the role of ports in the transport chains}

In the light of the foregoing discussions, ports which are interfaces between inland and sea transport modes no longer attract traffic simply by providing efficient cargo handling facilities and good hinterland connections. Ports must fit into the strategies of shipping lines in order to retain their loyalty. Shipping lines or carriers prefer ports that have good maritime access, adequate depth at entrance channel to accommodate large vessels, which they now deploy for their operations. Thus ports must be properly positioned to attract traffic from immediate hinterland and even distant hinterlands. This is an important feature required within the port and in relation with other foreign ports. Notteboom and Winkelmans (2004) sum up these developments thus: major port clients consider ports merely as a subsystem in the logistics chain. Accordingly, they concentrate their service packages not on the ports' sea-to-land interface but on the quality and reliability of the entire transport chain. Port choice becomes more a function of network costs (Notteboom \& Winkelmans, 2004). The ports that are being chosen are those that will help to minimize the sum of sea, port and inland costs. Furthermore, some shipping lines go into contractual relationship with some ports to develop and maintain terminal facilities in order to reduce ship's time in port. In sub-Saharan African ports, such 'private' operation of port terminals can be seen in Djibouti, Dar es salaam and Maputo, where contracts were signed with Dubai ports international (United Arab Emirates), ITCSI (Philippines), with a local partner Vertex, and MPDC (made up of three international partners from Portugal, Sweden and the united Kingdom) and the Local partners mobilization Railways, respectively (UNCTAD 2003). Maersk/Sealand operates a private container terminal in Algeciras in North Africa. Besides these arrangements, carriers also go into negotiations with port authorities for favorable services charges and conditions. The extent of their influence over ports is such that ports lose important clients (carriers) not because of deficiencies in port infrastructure or terminal operations, but because the client has rearranged its service networks or has engaged in new partnerships with other carries. Accordingly, to meet carrier strategies, ports have been compelled to adopt best practices (benchmark) and offer their services on a worldwide basis by collaborating with neighboring ports and others in different parts of the globe. This has enabled them to seek areas to co-operate and compete i.e. co-opetition, see Song (2003). Port networking with overseas ports improves the ports' functioning in the global transport system through exchange of knowledge and ideas. Co-operation with overseas ports is often materialized through sister city agreements and less formal mutual exchange of information (Notteboom \& Winkelmans, 2001b).

\section{Conclusion}

From the foregoing, it would be seen that on the demand side of port services, port patronage generally is related to the strategies of large global shipping lines (carriers) and the transport needs of large shippers. These actors essentially control transport chain decisions regarding which ports are selected or not. Greater carrier choice in routing cargo and parallel advances in logistics and supply chain management have thus changed competition from one between ports to one between supply chains (Barros, Haralambides, Hussain \& Peypoch, 2011). There has been attempt also, to present the picture of interaction of global transportation chain elements: shippers, carriers, port etc. in liner shipping operations connecting ports. It is relevant to the understanding of the role of ports in the following ways: ports are now expected to compete on the basis of number and traffic generating capacity of their hinterlands and not on location. Carriers are more than likely going to choose ports that guarantee high traffic owing to their connection to many hinterlands.

Ports situated along routes chosen by global carriers are expected to offer speedy services to minimize route costs. Shippers who serve as aggregators or consolidators may require greater port space especially in dry ports. Good hinterland intermodal connections improve chances of ports with the global carriers who now offer door to door services in vertically integrated arrangements with inland transport companies. The nature of shipping containers and vessels employed by the global carriers' means that ports should have adequate modernized cargo handling facilities and suitable drafts to accommodate mega vessels deployed by these operators. Therefore to realise expectations of the transportation chain partners who use ports, a strategic framework incorporating the above elements must be developed and implemented by national port administrators and planners if viability of their ports must be achieved given the prevailing structural scenarios in the transport chains. 


\section{Appendix A. Supplementary material}

Supplementary data associated with this article can be found, in the online version, at https://jsdtl.sciview.net

\section{Funding}

The authors received no direct funding for this research.

\section{Citation information}

Onwuegbuchunam, D. E., Okeke, K.O., Igboanusi, C., \& Ugboma, O. (2018). Structural changes in the global transport chain: Implications for ports. Journal of Sustainable Development of Transport and Logistics, 3(1), 22-28. doi:10.14254/jsdtl.2018.3-1.2.

\section{References}

Baird, A. J. (2002). The economics of container transhipment in Northern Europe. International Journal of Maritime Economics, 4(3), 249-280.

Barros, C., Haralambides, H., Hussain, M., \& Peypoch, N. (2011). 17 Seaport efficiency and productivity growth. International handbook of maritime economics, 363-382.

Chee, L. (2016). Reasons for mergers and acquisitions in the container shipping sector: A qualitative analysis of structural factors and market behaviour. Unpublished B.Sc. Thesis. Department Urban, Port and Transport Economics, Erasmus School of Economics. Erasmus Universiteit Rotterdam

Drewry Maritime Advisers. (2016). Consolidation in the Liner Industry White paper. Retrieved from https://www.drewry.co.uk/AcuCustom/Sitename/DAM/003/Drewry_WhitePaper_Liner_Industry_Cons olidation_March_2016.pdf.

Heaver, T. D. (2002). The evolving roles of shipping lines in international logistics. International Journal of Maritime Economics, 4(3), 210-230.

Karimi, A., Srinivasan, R., \& Han, P.L. (2002). Supply chain management. Cepmagazine, 14(2). Retrieved from https://www.cepmagazine.org

Notteboom, T. E., \& Winkelmans, W. (2001). Structural changes in logistics: how will port authorities face the challenge?. Maritime Policy \& Management, 28(1), 71-89.

Notteboom, T.E and Winkelmans, W. (2004). Factual report on the European port sector. Final Report of European

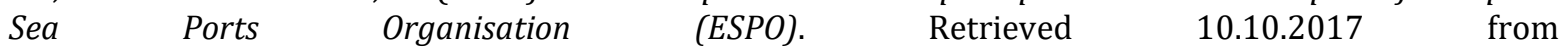
https://www.espo.be/media/espopublications/ESPOFactualReportonthePortSector.pdf.

Onwuegbuchunam, D.E (2013). Port selection criteria by shippers in Nigeria: A discrete choice analysis. International Journal of Shipping and Transport Logistics, 5(4/5), 532-550. https://doi.org/10.1504/IJSTL.2013.055288

Song, D. W. (2003). Port co-opetition in concept and practice. Maritime Policy \& Management, 30(1), 29-44.

Tongzon J. (2002). Port choice determinants in a competitive environment. In Annual Conference and Meeting of the International Association of Maritime Economists. Panamá: Iame. Retrieved from http://www.transport.hostra.edu.com.

UNCTAD. (2003). Transport costs in developing economies. UNCTAD. Review of maritime Transport. World Bank Working Paper http://www.puc-rio.br/services.docs/transpor.ext.

Wagner, S. (2015). M\&A trends in the maritime sector. Shipping Insights Briefing. Retrieved 28.11.2017 from https://assets.kpmg.com/content/dam/kpmg/pdf/2015/11/2015-shipping-insights-briefing3.pdf.

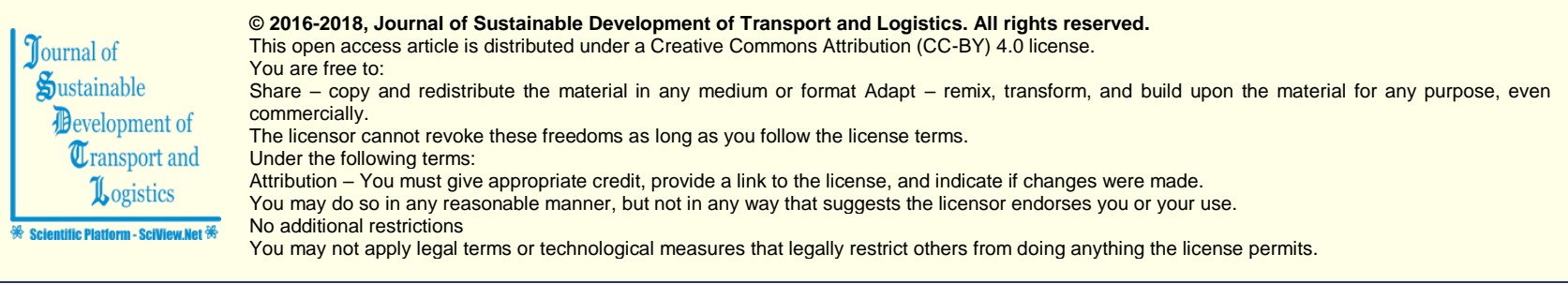

Journal of Sustainable Development of Transport and Logistics (ISSN: 2520-2979) is published by Scientific Publishing House "CSR", Poland, EU and Scientific Publishing House "SciView", Poland, EU

Publishing with JSDTL ensures:

- Immediate, universal access to your article on publication

- High visibility and discoverability via the JSDTL website

- Rapid publication

- Guaranteed legacy preservation of your article

- Discounts and waivers for authors in developing regions

Submit your manuscript to a JSDTL at https://jsdtl.sciview.net/ or submit.jsdtI@sciview.net 